The previaus statistics of the four weeks ending on the 26 th June show that 27 cases were admitted during these four weeks, of which 11 were typhus, and 7 of the 11 were from St. Olave's Union. "Typhus," in the language of these hospitals, of course means typhus; typhoid cases being properly charaeterised as enteric fever, to avoid all confusion. Typhus has existed in that neighbourhood for some little time: 12 cases were admitted therefrom during the four weeks ending May 1st.

At Homerton Fever Hospital as many typhus cases have been admitted in the eight months since October as in the previous twelve months. The following are the particulars. From the 2nd Oetober, 1872, to June 24th, 1873, 224 cases of fever were admitted: namely, simple continued fever, 36 cases; scarlet fever, 45 ; enteric fever, 69 ; typhus fever, 74 cases. About the end of April last typhus appeared in the parish of Whitechapel in the neighbourhood of the mintnamely, in Cartwright-street, Royal Mint-street, Cooper'scourt, Hay's-court, Kettleby-court, \&c. From that time to the 13 th June there were received about 50 cases of typhus, the subjects all natives of Ireland or born of Irish parents. From the 13th to the 25th of June there were no admissions of typhus from Whitechapel, but from June 25 th to July 29 th 6 eases were received. The number of cases in the hospital at the last-mentioned date was 57 : namely, scarlet fever, 8 ; typhus, 23 ; enteric, 26 . Of course a few cases not of specific fever have been admitted.

Clearly there is nothing like an epidemic of typhus. And it is to be hoped that before winter, which is its favourite season, involving the overcrowding and the underfeeding of the poor, the medical officers of health for the districts in which these typhus nests exist will be able to give us a satisfactory account of its disappearance. We cannat help, however, expressing a fear that such nests of typhus indicate an overerowding in this metropolis which may become very serious if a wise legislation does not take it more into consideration.

\section{THE CHOLERA.}

Cholera has broken out in Ibralia. Up to July 21st, 29 deaths have occurred, nearly all in the lower orders. There were 33 deaths in Galatz in the week ending July 22nd. According to official publications, cholera has also appeared at Imail and Cabul. In Buda-Pesth the cases for the week ending the 22nd were 315 , and the deaths 150. The numbers the previous week were 190 and 80 respectively. In the week ending the 29 th, the numbers were 358 and 160 . The disease appears to be gaining ground.

It appears from a statement made by the town council of the City of Dresden that since the middle of May there have been 21 cases of cholera, and of these cases 8 had a fatal termination, and that 15 of the cases were imported ones. Since July 17 th there has not been a fresh case.

Cholera is stated to have broken out in Bosnia, 25 cases having occurred, of which 8 were fatal. It is reported that cases of cholera have occurred in Hamburg, though the disease has appeared only in some low-lying part where sanitary arrangements are bad. The town itself is, we believe, free.

Vessels arriving in Danish ports from Konigsberg are compelled to be inspected before communication with the shore is allowed. A penalty is imposed for breach of this regulation.

Up to the end of last week, the cases of cholera in Konigsberg appear to have been 46, and the deaths 29; but it does not seem to be on the increase.

The Peninsular and Oriental steamers arriving at Alezandria from Venice are now subjected to quarantine.

The Lisbon Government has declared the Black Sea ports of Turkey suspected of cholera, and also the ports of the Austro-Hungarian Empire. The same Government has likewise declared the cities of Memphis and Nashville, in the United States, and the port, of Venice, infected with cholera, and the ports of the Mississippi suspected. It likewise declares the Baltic ports of Sweden, Denmark, and Russia free from the disease.

Two cases have occurred among the troops in Trieste, one proving fatal.
There have been 20 cases and 12 deaths in Helsingborg. The following is, according to the Vienna Gazette, a statement of the cholera eases in that city :-On July 17th, 9 ; on the $18 \mathrm{th}, 8$; on the $19 \mathrm{th}, 10$; on the $20 \mathrm{th}, 6$; on the 21 st, 10.

Cholera has appeared in Hungary.

Quarantine is imposed at Copenhayen on all arrivals from Helsingborg, which is only a few miles from the Danish coast. The Danish sanitary authorities have appointed officers to visit the houses of the poor, and ensure the removal of nuisances.

All arrivals in Spanish ports from the Austrian ports of the Danube aud from the Vistula which had put to sea at a date subsequent to July 1st last will be sent to a lazaret for quarantine purposes.

The following are the particulars of cholera in Parma : July 24 th to $27 \mathrm{th}, 17$ cases, 10 deaths; on the 28 th, 2 cases ; on the 29 th, 3 cases, 3 deaths; on the 30 th, 3 cases, 2 deaths.

The disease, though advancing slowly in Italy, is said to be of a mild type.

A fatal case of cholera is reported to have occurred on board a British ship at Ronen. It is also reported that other cases have occurred in the vicinity of Rouen.

It appears that the first case of cholera at Helsingborg occurred on July 23 rd, and that since then the disease has continued to spread, the deaths being about 50 per cent. Choleraic diarrhoea is reported as being very prevalent among the lower classes.

A hospital ship has been moored at Warholm, about twenty miles below stockholm.

\section{Coxrespontence.}

"Audi alteram partem."

\section{NAVY SURGEONS.}

To the Editor of THE LANCST.

Sir,-On Wednesday, July 30th, I put the following questions in the House to the First Lord of the Admiralty :(1) Whether at present assistant-surgeons in the Royal Navy, even when not serving on foreign stations, are denied. the privilege known to be generally accorded to assistantsurgeons in the army, and to officers generally, of voluntarily retiring from the service; (2) Whether there is any limit of time to the refusal of the Admiralty to permit such naval medical officers to retire, or whether they are liable to be forced to remain in the service for any number of years at the pleasure of the Admiralty; and (3) Whether there are not at present navy medical officers on the halfpay list whose services could be had to supply the places of assistant-surgeons desiring to retire, but refused permission. To these questions I received the following reply:"That the right to refuse permission exists, no doubt, without limit as to time, but the practice is to permit navy surgeons to retire after they have seen service, and proved tbemselves deserving of the indulgence." To this was afterwards added, "That there were surgeons, but not many, on the half-pay list, available for duty."

I followed this up by putting on the Order-book of the House for Monday (August 4th) the following notice of motion :-To call the attention of the House to the present position of surgeons and assistant-surgeons in Her Majesty's Royal Navy in regard to voluntary resignation of their commissions, and the probable effects on the service. When it came on the forms of the House interfered to prevent it, and several notices in similar form on other subjects, from being brought on.

I think it is important that candidates for the Navy Medical Service should, without delay, and especially on the approach of competitive examinations, know accurately how they will stand when accepting commissions; and, therefore, I lose no time in making them acquainted with the particulars. It would be too long to allow matters to remain in doubt until the next meeting of Parliament in February, 1874.

The present state of the Naval Medical Service is this, 
that " if navy surgeons have not seen active service, and proved themselves deserving of the indulgence, they will not be allowed to retire for one year, or ten years, or it may be for life." When a combatant officer or a surgeon in the Indian or British army asks to retire, this condition is never imposed on him - that he is not to be allowed to retire until he has seen service, and until he has proved himself worthy of the indulgence. On the contrary, and very properly, if he shows disinclination for duty, it is allowed him to retire without delay. No one ever heard of such a reply being given to an officer in the Horse Guards, or in any regiment of the line, or to a military surgeon, "You will not be permitted to retire until you have seen service and proved yourself deserving of the indulgence."

One of the reasons assigned for this exceptional treatment of navy surgeons is that they have received some instruction at Netley Hospital on entering the service, and that they have no right to expect to be allowed to retire from the service after having received such instruction at the public expense until they have repaid it by being out on active service. But this argument would apply equally to army surgeons, for they too are sent to Netley, and yet there is no compulsion on them to remain in the service. But what is the amount of instruction on which so much stress is laid? 'It is for a period, it may be, of two or three or four months, according to circumstances, at the miserable pittance of five shillings a day-a pittance not enough to keep a schoolboy of twelve years of age in clothes, washing, and food. And do these surgeons give nothing in return for this miserable pay? They give far more than value for it. They have under their immediate charge the sick and wounded in hospital; and if the State had not these gentlemen at five shillings per day, the State would have to pay more than double to their own half-pay surgeons to do the same duty. The gentlemen thus paid this miserable pittance are not students, but young men fully and legally qualified by their degrees or licences to be elected as medical officers of the best and largest hospitals in the United Kingdom. What would be thought of its being said by the Commanderin-chief to a cavalry officer, if he desired to retire within a year after the-date of his commission, "You shall not retire until you have seen service; and, moreover, you have had three months' instruction in the riding-school of the depôt at the public expense, and you must stay where you are and as long as I please until you have proved yourself deserving of the indulgence"? Yet this is the language now adopted and addressed to the surgeons in the navy. If this is to be the practice, it is worse than the enlistment of sailor or soldier, for a sailor or soldier can look out to the termination of a certain number of years, and can purchase his discharge; but the unfortunate naval surgeon sees no prospect of release before him ; indeed for him the 'scutcheon over the portal of the Naval Department may truly now bear upon it the words written over the portal of the "Inferno":

"Lasciate ogni speranza, voi ch' entrate." " All hope abandon, ye who enter here.")

He is worse off than the kidnapped Fijian or "coolie," who may, if he can, escape from bondage.

A document has been forwarded to me from the Admiralty to show that navy surgeons, on entering the service, have bound themselves irrevocably for life, if such be the pleasure of the Admiralty. It is as follows: " $I, A$ B, a candidate for employment in the Medical Department of the Royal Navy, do hereby engage for general service, and attest my readiness to proceed on duty abroad whenever required to do so." And this is adduced as proof that the navy surgeon has bound himself, neck and heels, to remain his lifetime, if so desired, in the service. I cannot read it so. I read it in the plain, common, and fair sense of the words-that, while he remains in the service, he will go wherever ordered, but not that he is absolutely and for ever to be forced to remain in the service; that he is to be deprived of the privilege of retiring enjoyed by other officers in the navy and by all offcers and surgeons in the army. If it were to be deemed expedient to enforce compulsory service, the notice ought to be intelligible and plainly worded in terms such as these:- " You are hereby to understand that you are never to be allowed to resign until you have seen service, and proved yourself worthy of the indulgence to the satisfaction of the Lords of the Admiralty."

Three cases have come to my knowledge in which permission to resign has been refused. I believe one or two more have occurred within the last few months. The docu. ments from which I quote are in my possession.

The first, A. B., was appointed in February, 1872. In May, 1873 (about a year and three months afterwards), from some domestic and pressing circumstances, it became necessary that he should abandon professional pursuits and devote himself to the care of his father's business. He accordingly sent in his letter of resignation; that was more than a year and a quarter after his appointment, and while he was on harbour-ship or hospital duty in England. He was refused. He again applied. There was no reply to this second application; but on the 21st of July, 1873, two months after he had resigned, he was ordered to proceed to a flagship in India, and obliged to sail last Thursday under threat of court martial; and the defence for this proceeding is that he is not to be allowed to resign until he has seen active service. But, even if the rule were a good one, he never had the opportunity of seeing active service; he was kept the whole time on duty in harbour ships or on shore, and then punished for not having ceen what it was not in his power to have seen. If this gentleman had been on active or foreign service at the time of his application, and his place could not be supplied, I could understand a refusal until his place could be supplied; but sending him an order to embark for foreign service more than two months after his resignation shows that his services were not required at the time of his resignation, and is, it appears to me, an aggravation of the injustice and hardship.

In the second case the circumstances were similar : first an application for leave to retire; secondly, a refusal; thirdly; a second application; and the only reply to this an order to embark in'about forty-eight hours for the West Coast of Africa, followed by a communication from the Admiralty that unless he returned immediately to Plymouth he would be arrested by the police as a deserter. I do not want to question the legal right of the Lords Commissioners to order a navy surgeon or any other naval officer to be arrested by the police, even though some months had elapsed after he had sent in his resignation, and to force him to remain in the service; but I strongly dispute its expediency. Let us imagine what would be the feelings of officers and men if they saw the surgeon, to whom they were to entrust life and limb for voyage after, voyage, brought on board by the police as a deserter, and informed that his services were to be had only under compulsionservices that never can be trusted and relied upon unless they come with a willing heart. This is not the relation that ought to exist between the officers and men of a ship of war and their surgeon, the officer to whom they should ever look upon as their voluntary and devoted friend on the most trying occasions of their lives.

The third case is so similar to the last that I do not think it necessary to go into its details-the same story, the same application to resign, the same refusal from the Lords of the Admiralty, application renewed, refusal repeated, and then the second refusal quickly followed by an order to go to a station as before on the West Coast of Africa.

There is really, as far as I can see, no excuse for what has occurred, and it will be impossible to divest the minds of the public and of the naval surgeons themselves as a body of the impression that the post hoc did really follow as a sequence propter hoc, that the order for the West Coast of Africa was an order to be interpreted as an intimation to navy surgeons that they must not henceforth dare to ask for the same privilege of retiring that is freely granted to other officers in their own service, and to all in the army at home and abroad; that they must be content to remain in a slavery to which no other officers, and not even private soldiers or men before the mast, are subject, and that if they dare to think otherwise the same penalty awaits them. It will be a great misfortune to the officers and men of the Royal Navy if this course is to be persevered in of refusing permission to naval surgeons to resign, for good men will not enter the navy as surgeons, and it is of more consequence to the navy than to the army that they should get good and willing men, for the navy is more dependent on its medical officers than the army. I think that navy surgeons should be treated as all other surgeons and officers are treated-that is, allowed to resign their appointments when not engaged on active service or on foreign stations where their places cannot be immediately supplied, and that 
the cases of the three or four navy surgeons who, under the circumstances I have mentioned, have been refused permission to retire, should be reconsidered. The navy surgeons will soon find out for themselves what they are worth. I believe that brains and beef are equally commodities in the market of the world, and must find their own value, and if young men will continue to enter the navy as surgeons they will do it at their own peril, for they have now knowledge of what is before them; but those who conduct the affairs of the Royal Navy should weigh well in their own minds whether the facts and views now put forward are worthy of their attention. Let it be remembered that there is now a vast field opened to young surgeons in thousands of passenger and trading steamers over the whole world, with better pay, with more comforts, and with liberty to retire when they please; and that foreign governments are offering large bonuses for surgeons. I have heard it asserted that unless compulsory service is enforced in the Royal Navy, as contradistinguished from the army, men who enter the Royal Navy would not remain in it, so great are its disadvantages. If there be any foundation for the assertion, it presents a melancholy picture of the management of the Naval Medical Service.

I am Sir, very truly yours,

House of Commons, Aug. 5th, 1873. D. J. Corrigan.

\section{TYPHOID IN MARYLEBONE.}

To the Editor of THE LANCET.

SIR,-It has come to my knowledge that many cases of typhoid fever have recently occurred in this and neighbouring parishes amongst families who are supplied with milk from the same source. I shall feel under great obligation to any of your medical readers who may at the present time be treating the disease, or have recently done so in this or the neighbouring parishes, to inform me, with the least possible delay, of the source from which in these instances the supply of mills to the family has been obtained.

The great importance to the health of the community of the matter which my official position calls upon me to investigate is $\mathrm{my}$ apology for asking your valuable assistance. I am, Sir, your obedient servant, J. WhitMoRE, M.D.,

Medical Officer of Health for the Parish of St. Marylebone.

August 6th, 1873.

\section{GROUSE DISEASE.}

To the Editor of THe LaNCET.

Str,-I beg to furnish you with some information respecting the grouse disease.

All birds I have examined during this or former epidemics contained tapeworm. In May last I obtained two birds, one from the neighbourhood of Kirriemuir, the other from Sir Thomas Gladstone's moor, near Fettercairn. Both were in good plumage; the one was emaciated, the other in good condition. The portion of the intestine above the tapeworm was impacted with dry vegetable matter, while the lower part of the gut contained liquid yellow feculent matter. I do not know to what extent the presence of tapeworm in grouse may be consistent with comparative health, and have never myself examined healthy birds for it, but it is well known that all wild animals are liable to be infested with entozoa.

In the winter of 1846 immense numbers of the razor-billed auk (Alca torda) were thrown up dead on the shores of the Firth of Forth. In all the specimens I examined the intestines contained tapeworm and other entozoa, but so familiar was I with these parasites in marine fishes and other animals, that I attributed the auk mortality at the time to the severity of the weather; but certainly neither before nor since have I seen so many of these birds cast on the shore, though there have been many more severe winters.

Supposing tapeworm to be the cause of the grouse mortality, we can easily understand how overstocking and the extermination of predacious birds may help to increase the evil; but when we find it occurring with a certain periodicity every five or six years, it is clear there must be some other cause for the spread of the disease.

Probably a careful study of the history of the grouse tapeworm, taken along with the meteorological conditions of the seasons and the conditions and moisture of the various moors, would throw some light on the subject.

Last season, being exceptionally wet, must have been peculiarly favourable to the preservation of the eggs of the tapeworm, many of which in a dry season would have been lost. Were previous epidemics preceded by wet seasons? I have neither the opportunity nor the necessary time at my disposal for carrying out investigations on this matter, but were those most interested-namely, the proprietors and lessees of moors- to offer a prize for the best essay on the grouse disease, $T$ have no doubt that some reliable information would be elicited.

I am, Sir, yours truly,

Sunnyside, Montrose, July, 1873. James C. Howden.

\section{PENCIL-CASE THERMOMETERS.} To the Editor of The LaNcet.

Sir,-Referring to the conflicting statements of your three correspondents in the last number of THE LANCET, I beg leave briefly to observe that altbough the registration of my pencil-case thermometer was only effected on the 3rd ult., the idea was originated by me some months before, and it would be easy for me to produce proof in support of this statement from more than one of my brother medical practitioners and others.

The simple slide pencil-case possesses the important qualities of simplicity and lightness over the more cumbersome and complicated, and therefore more expensive screwpropelling arrangements, which I abandoned in favour of the simpler device.

Desiring to avoid further trespass on your valuable space, I will merely add that my registration document, which one of your correspondents is good enough to esteem so lightly, includes other important features in addition to the form of the inside case, and in virtue or these, if for no other reason, I trust it may continue to hold a worthiex place than the " waste-paper" basket.

I remain, Sir, yours obediently,

R. HaRvey Hilliard, M.D.

Belgrave-terrace, Opper Holloway, Aug. 2nd, 1873.

\section{PARIS.}

(From our own Correspondent.)

In connexion with a thesis recently published by $D$ r. Terrillon, and with a communication presented to the Société Médicale des Hôpitaux of this city by Dr. Féréol, there has been an important discussion at that Society on a subject of much interest-namely, "albuminous expectoration consecutive on thoracentesis." In 1863 Dr. Pinault had already drawn attention to the fact, cases of which were since published by various medical men, and Dr. Terrillon collected them all, adding observations of his own. The albuminous expectoration may take place after very simple cases of thoracentesis. Sometimes immediately after the operation, but more commonly some hours later, the patient is affected with dyspncea, and throws up a quantity of slimy, yellowish, frothy liquid, which may oecasionally attain the amount of two litres. When the liquid is allowed to rest, it presents three successive layers: an abundant layer of froth, a second layer of yellowish liquid, sometimes containing sputa, and lastly a third layer at the bottom of the vase, and which, on microscopical examination, shows a quantity of epithelial cells, white globules, and a few blood-corpuscles. The chief characteristic feature of this layer is that when treated by nitric acid it exhibits an abundant quantity of albumen, which is not the case in simple bronchorrhoea.

Dr. Terrillon mentions three clinical forms of the phenomenon: one a slight one, characterised by moderate dyspnoea and abundant expectoration; the second an intense one, with marked dyspncea and cough, and which may last several days or weeks, and return on each puneture; the third form is the gravest, and is attended by suffocation. The abundant liquid fills the bronchi and 